() О. І. Лотоцька, к.т.н., доцент, А. Р. Гудзь, магістр, КПІ ім. Ігоря Сікорського, Київ, Україна

\title{
ОЦІНЮВАННЯ ОПТИЧНОЇ ГУСТИНИ ВІДБИТКІВ НА МЕТАЛІ ВИГОТОВЛЕНИХ ТЕРМОСУБЛІМАЦІЙНИМ МЕТОДОМ
}

\author{
Проведено експериментальні дослідження оптичної густини \\ на металевих пластинах, виготовлених термосублімаційним \\ друком. Встановлено закономірності оптичної густини \\ від відсотку насиченості плашки для кожного з кольорів \\ СMYК для відбитків на металі під «золото» та під «срібло».

\section{Ключові слова: термосублімаційний друк; термотрансферний друк; оптична густина; CMYK; металева пластина; технологічні параметри; сублімаційні фарби; сублімаційний папір.}

\section{Постановка проблеми}

Отримання відбитків на різноманітних матеріалах з індивідуальним дизайном вимагає окрім якості, ще й великої оперативності та мобільності. Якщо раніше віддавали перевагу трафаретному або тампонному способам друку, для отримання відбитків на таких матеріалах, як дерево, скло, тканина, пластикові та металеві вироби тощо, то тепер, найчастіше вони виявляються неефективними й постає питання заміні їх іншими видами друку. Сьогодні існує безліч технологій, які дають змогу наносити зображення на різноманітні матеріали з високою швидкістю і при цьому отримувати відбиток з невеликою собівартістю. Саме до таких технологій можна віднести термотрансферний друк [1].

Будучи однією з найпрогресивніших технологій у світі кольорового друку, кольорова сублі- маційна технологія $€$ ідеальним засобом забезпечення фотографічної якості зображення [2].

На сьогодні в Україні і світі стандарти, які б чітко описували вимоги та норми термосублімаційного друку знаходяться у стадії розробки. Поліграфічні підприємства найчастіше користуються інструкціями, які надають виробники устаткування та матеріалів для термосублімації. Існує необхідність детального дослідження технології та її особливостей, тому актуальним $€$ дослідження якості зображення, отриманого термосублімаційним друком на металі.

\section{Аналіз попередніх досліджень}

У наукових працях Т. В. Розум у співавторстві з М. Нечипорчуком [1, 3] проведено аналіз новітніх технологій, які дають змогу наносити зображення на різноманітні матеріали з високою

(C) $2017 \mathrm{p}$. 
швидкістю і при цьому отримувати відбиток з невеликою собівартістю. Авторами вказано особливості переваги термотрансферного друку: мінімум витрат, оперативність процесу виготовлення, простота освоєння (не требує високої кваліфікації персоналу), широкі зображувальні можливості, висока роздільна здатність друку.

Технологія сублімаційного термотрансферного друку дозволяє отримати яскраві зображення з фотографічною якістю, які будуть стійким до дії впливу навколишнього середовища, оскільки фарбувальні речовини знаходяться в структурі поверхні виробу. Недоліком цієї технології є можливість друкувати тільки на світлих поверхнях $[1,3]$.

У роботі науковця О. І. Проць «Використання технологій офсетного друку і Grawerton для відтворення багатофарбових зображень на металі» [4] досліджуються зміни колірних характеристик відбитків, отриманих технологією Grawerton та офсетним способом друку на металевій поверхні, порівнюється якість відбитків на металі за колірними характеристиками, отриманих сублімаційним та офсетним методами.

Процес сублімації фарби з проміжного носія на металеву основу ілюструє тристадійна модель механізму переходу дисперсних барвників на поверхню металу:

- перша стадія - при підведенні тепла до проміжного носія зображення барвник у шарі фарби з твердого стану переходить у газову фазу і через пори в'яжучого друкарської фарби дифундує в повітряний прошарок між проміжним носієм і субстраTOM;
- друга стадія - дифузія пари барвника в повітряному прошарку до поверхні субстрату;

- третя стадія - сорбція парів барвника поверхнею з подальшою їх дифузією всередину субстрату [4].

На основі літературно-патентного пошуку виявлено, що проблемі дослідження якості приділяють багато уваги науковці, але не дослідженою залишається залежність оптичної густини від технологічних параметрів на металах різного кольору.

\section{Мета роботи}

Дослідження впливу технологічних режимів термосублімаційного друку на оптичну густину відбитків металевої пластини.

\section{Результати проведених досліджень}

Тестові зразки виводились на сублімаційному принтері Epson Stylus Photo 1410 сублімаційними фарбами INKSYSTEM на папері для сублімації фірми Lomond, масою 1 м² 100 г. Для термоперенесення використовували прес Schulze Blue Line Size 3.

Задруковуваним матеріалом $€$ метал, а саме алюміній $з$ покриттям «під золото» та «під срібло» товщиною 0,5 мм. Для виготовлення зразка використано прозорий двокомпонентний акрило-поліуретановий лак фірми SUBLICOAT для обробки різних матеріалів (скло, метал, тощо), наноситься методом розпилення.

Для післядрукарської обробки відбитка на металі використовується лак фірми Lomond. Лак наносять аерографом на повністю висушений відбиток не раніше ніж через 24 год після друку. 
Для проведення детального аналізу відбитка на металі, отриманого термосублімаційним методом, була створена тестформа для проведення вимірювання на спеціальній контрольній шкалі з відносною площею розтискування від 10 до $100 \%$. За допомогою градаційної шкали можна контролювати точність відтворення тонів.

Дослідження показників оптичної густини. Перехід фарби з основи на метал відбувається

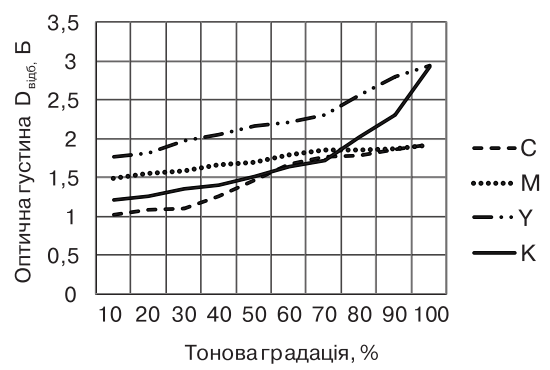

Рис. 1. Залежність оптичної густини від відсотку насиченості плашки за температури $380^{\circ} \mathrm{F}$, за 50 с при тиску $340 \mathrm{krc/ \textrm {M } ^ { 2 }}$ на алюмінієвій пластині «під срібло»

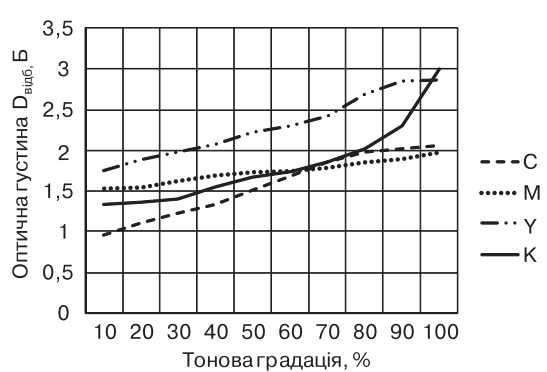

Рис. 3. Залежність оптичної густини від відсотку насиченості плашки за температури $380^{\circ} \mathrm{F}$, за 70 с при тиску 330 кгс/м² на алюмінієвій пластині «під срібло» при підвищеному тиску та високій температурі за певний проміжок часу, саме тому проводиться дослідження впливу зміни таких технічних параметрів на якість відбитку.

Зразки були надруковані на алюмінієвій пластині марки АМг1 з кольором поверхні «золото» та «срібло» при температуpax в межах $360 \ldots 400^{\circ} \mathrm{F}$, за $30 \ldots$ 70 с за тиску 320...340 кгс/м².

Для проведення аналізу оптичної густини відбитка про-

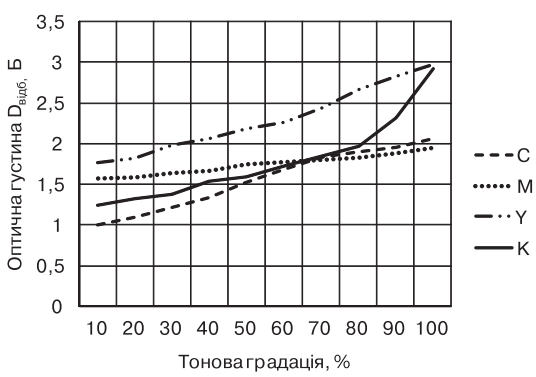

Рис. 2. Залежність оптичної густини від відсотку насиченості плашки за температури $400^{\circ} \mathrm{F}$, за 50 с при тиску 330 кгс/ $\mathrm{M}^{2}$ на алюмінієвій пластині «під срібло»

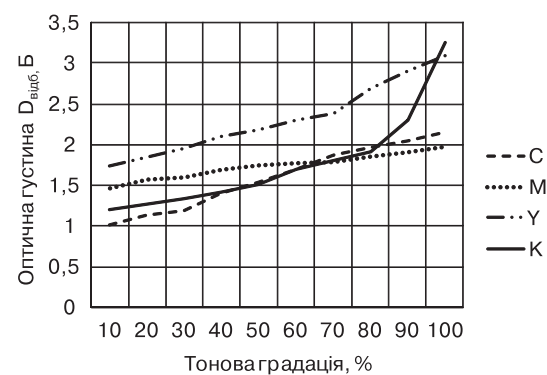

Рис. 4. Залежність оптичної густини від відсотку насиченості плашки за температури $380^{\circ} \mathrm{F}$, за 50 с при тиску 320 кгс/ $\mathrm{M}^{2}$ на алюмінієвій пластині «під срібло» 
водиться вимірювання оптичної густини шкали CMYK по градаціям від $10 \%$ до $100 \%$ у трьох точках та розраховується середнє арифметичне значення.

На рис. 1-14 наведено графіки залежності оптичної густини від відсотку насиченості плашки за різних технологічних параметрів для кожного з кольорів CMYK для відбитків на металі «під золото» та «під срібло».

Аналізуючи денситометричні дані, проілюстровані на графіках

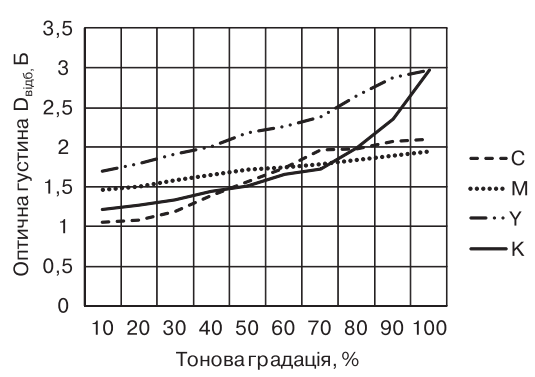

Рис. 5. Залежність оптичної густини від відсотку насиченості плашки за температури $360^{\circ} \mathrm{F}$, за 50 с при тиску 330 кгс/м² на алюмінієвій пластині «під срібло»

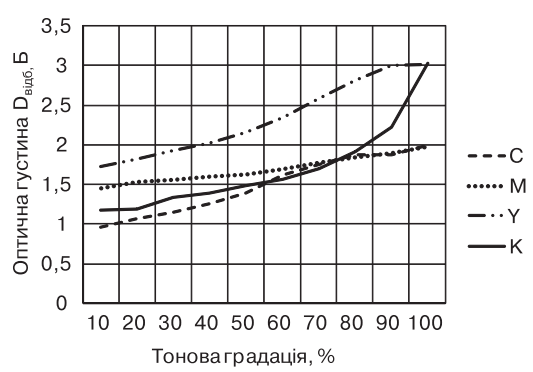

Рис. 7. Залежність оптичної густини від відсотку насиченості плашки за температури $400^{\circ} \mathrm{F}$, за 70 с при тиску 340 кгс/ ${ }^{2}$ на алюмінієвій пластині «під срібло» залежності, можна стверджувати, що більш стабільну передачу фарби мають тріадні фарби на алюмінії «під срібло». Відбитки на алюмінії «під золото» не набувають оптимальних значень, особливо для пурпурового кольору. Для друку зображень фотографічної якості такий колір металу не рекомендовано.

Підтверджуємо, що технологічні параметри рекомендовані виробником обладнання дійсно забезпечують високу якість,

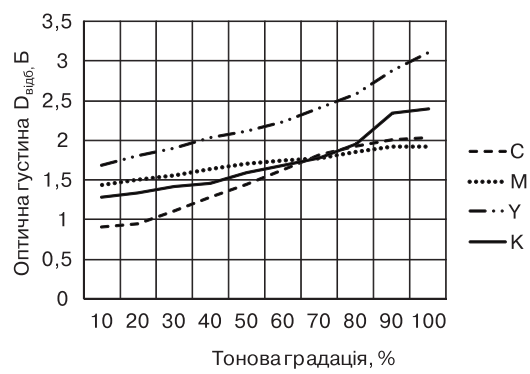

Рис. 6. Залежність оптичної густини від відсотку насиченості плашки за температури $380^{\circ} \mathrm{F}$, за 30 с при тиску 330 кгс/м² на алюмінієвій пластині «під срібло»

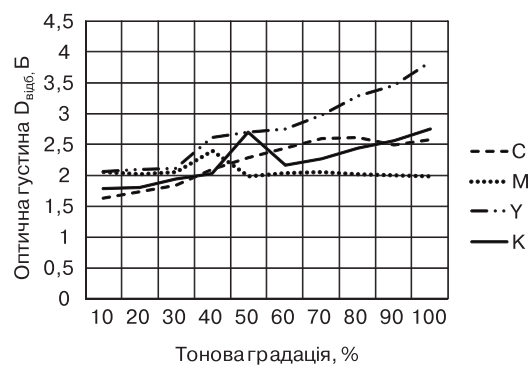

Рис. 8. Залежність оптичної густини від відсотку насиченості плашки за температури $380^{\circ} \mathrm{F}$, за 50 с при тиску $340 \mathrm{kгc/ \textrm {M } ^ { 2 }}$ на алюмінієвій пластині «під золото» 


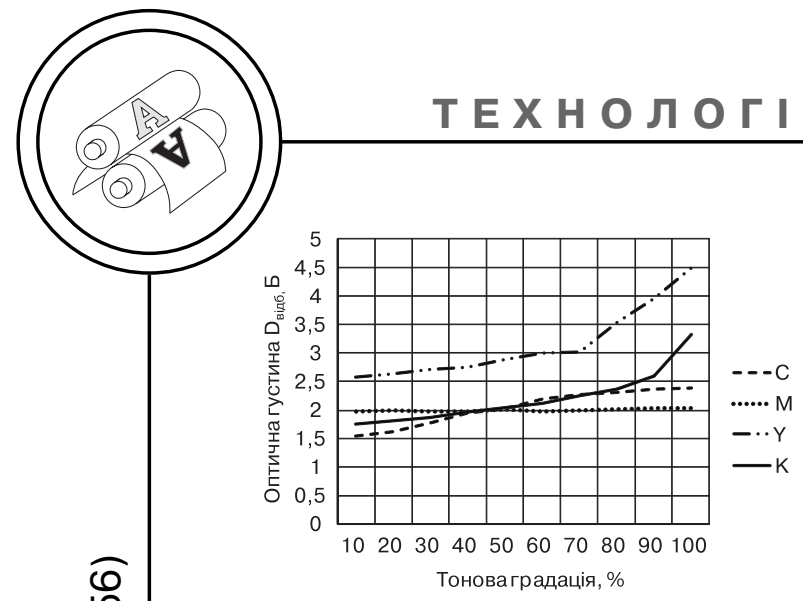

Рис. 9. Залежність оптичної густини від відсотку насиченості плашки за температури $400^{\circ} \mathrm{F}$,

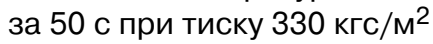

на алюмінієвій пластині «під золото»

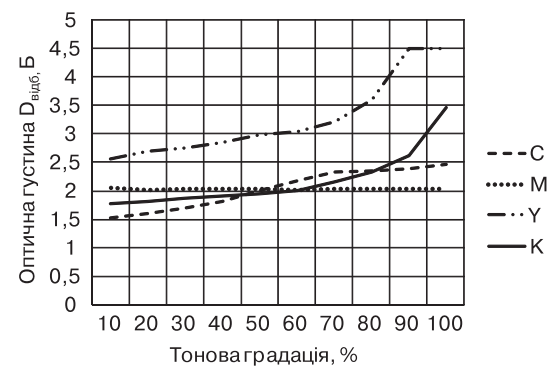

Рис. 10. Залежність оптичної густини від відсотку насиченості плашки за температури $380^{\circ} \mathrm{F}$,

за 70 с при тиску 330 кгс/ $\mathrm{M}^{2}$

на алюмінієвій пластині «під золото»

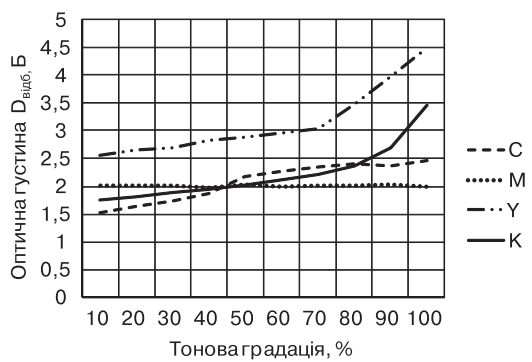

Рис. 12. Залежність оптичної

Рис. 11. Залежність оптичної густини від відсотку насиченості плашки за температури $380^{\circ} \mathrm{F}$, за 50 с при тиску 320 кгс/м² на алюмінієвій пластині «під золото»

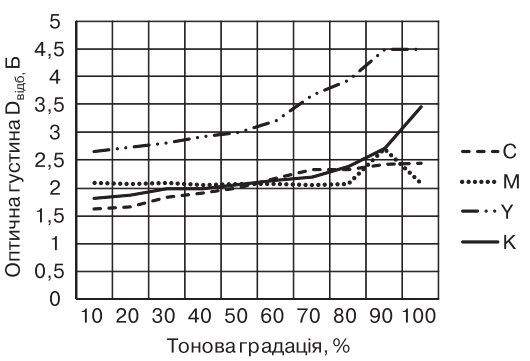

Рис. 13. Залежність оптичної густини від відсотку насиченості плашки за температури $380^{\circ} \mathrm{F}$, за 30 с при тиску 330 кгс/ ${ }^{2}$ на алюмінієвій пластині «під золото»

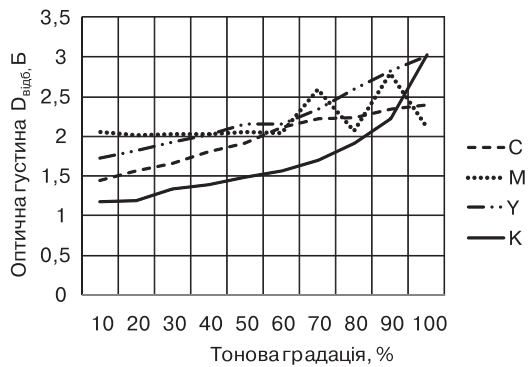

Рис. 14. Залежність оптичної густини від відсотку насиченості плашки за температури $400^{\circ} \mathrm{F}$, за 70 с при тиску 340 кгс/ $\mathrm{M}^{2}$ на алюмінієвій пластині «під золото» 
але потрібно зауважити, що колірні характеристики при одних і тих самих режимах різні на пластинах «золото» і «срібло».

\section{Висновки}

За результатами проведених експериментальних досліджень зразків із алюмінію під «золото» і «срібло», отриманих за допомогою зміни технологічних факторів друку термосублімаційним методом:

1. Розроблено тест-форму для забезпечення стабільності якісних параметрів відтворення зображення на металі у виробництві.

2. Підтверджено, що важливими технологічними параметрами термосублімаційного друку $€$ температура, тиск і час. Саме від цих параметрів в подальшо- му залежать колірні характеристики і завдяки ним можна стабілізувати кінцеву якість відбитків на металі протягом виконання замовлення.

3. Проведені дослідження показали, що ретельно підібрані витратні матеріали, обладнання і технологічні режими дозволяють отримати високу якість отриманого відбитка. Встановлено, що для друку зображень фотографічної якості алюмінієві пластини «під золото» не рекомендуються у зв'язку з тим, що відбитки не набувають оптимальних значень, особливо для пурпурового кольору.

Це ще раз підтверджує, що основою для визначення оптимальних технологічних факторів $€$ проведення практичних досліджень.

\section{Список використаної літератури}

1. Нечипорчук О. М. Технологічні особливості та систематизація способів термотрансферного друку [Електронний ресурс] / О. М. Нечипорчук, Т. В. Розум // Технологія і техніка друкарства. - 2008. - № 2. - С. 47-58. Режим доступу : http://ttdruk.vpi.kpi.ua/article/view/59769/55602.

2. Переваги термосублімаційного друку [Електронний ресурс] // EASYCODE Програмування, легко про складне. - Електрон. дані. - 4.06.2016. Режим доступу : http://easy-code.com.ua/2013/12/perevagi-termosublimacijnij-druku/. - Назва з екрана. - Дата перегляду : 4.06.2016.

3. Нечипорчук О. М. Тенденції розвитку технологій термотрансферного друку [Електронний ресурс] / О. М. Нечипорчук, Т. В. Розум // Технологія і техніка друкарства. - 2007. - № 1-2. - С. 56-59. - Режим доступу : http://druk.kpi.ua/ru/node/635.

4. Проць О. І. Використання технологій офсетного друку і grawerton для відтворення багатофарбових зображень на металі [Електронний ресурс] / О. І. Проць // Квалілогія книги. - 2013. - № 1. - С. 81-85. - Режим доступу : http://www.kim.uad.lviv.ua/uploads/book/kvalilog/Kvalilogy23 end.pdf.

\section{References}

1. Nechyporchuk, O. M. \& Rozum, T. V. (2008). Tekhnolohichni osoblyvosti ta sistematizatsiia sposobiv termotransfernoho druku [Technological features and ordering of ways of heat transfer printing]. Journal of Tekhnolohiia i tekhnika drukarstva - Technology and Technique of Typography, 2, 47-58. Retrieved from http://ttdruk.vpi.kpi.ua/article/view/59769/55602 [in Ukrainian]. 
2. Perevahy termosublimatsiinoho druku [Advantages of thermosublimation printing]. Journal of EASYCODE Programuvannya, legko pro skladne. - Programming is easy on complex. Retrieved from http://easy-code.com.ua/2013/ 12/perevagi-termosublimacijnij-druku/ [in Ukrainian].

3. Nechyporchuk, O. M. \& Rozum, T. V. (2007). Tendentsii rozvytku tekhnolohii termotransfernoho druku [Thermal transfer print tendencies' development]. Journal of Tekhnolohiia i tekhnika drukarstva - Technology and Technique of Typography, 1-2, 56-59. Retrieved from http://druk.kpi.ua/ru/node/635 [in Ukrainian].

4. Prots, O. I. (2013). Vykorystannia tekhnolohih ofsetnoho druku i grawerton dlia vidtvorennia bahatofarbovykh zobrazhen na metali [Use of technology and offset print grawerton playback multicolor images on metals]. Journal of Kvalilohiia knyhy - Qualilogy of book, 1, 81-85. Retrieved from http://www.kim. uad.Iviv.ua/uploads/book/kvalilog/Kvalilogy23 end.pdf [in Ukrainian].

\section{Проведены экспериментальные исследования оптической плотности на металлических пластинах, изготовленных термосублимационной печатью. Установлены закономер- ности оптической плотности от процента насыщенности плашки для каждого из цветов СМYК для оттисков на металле под «золото» и под «серебро».}

Ключевые слова: термосублимационная печать; термотрансферная печать; оптическая плотность; CMYK; металлическая пластина; технологические параметры; сублимационная краска; сублимационная бумага.

The article presents experimental research of the optical density of prints on metal obtained via the thermosublimation method. The studies of dye-sublimation printing were carried out using aluminum plate of brand Amg1 with a surface color of 'gold' and 'silver' at temperatures in the range of $360 . . .400^{\circ} \mathrm{F}$ during $30 . . .70 \mathrm{sec}$. under a pressure of $320 . .340 \mathrm{~kg} / \mathrm{m} 2$. The evaluation of prints was carried out on the basis of the graphs of dependence of optical density on the saturation percentage of a die at different process parameters for each of the CMYK colors for prints on metal by 'gold' and 'silver'. Inks on aluminium by 'silver' have a more consistent transfer of colors. Prints on aluminum by 'gold' do not acquire the optimal values, especially for purple color. This metal color is not recommended for printing images of photographic quality. There are important parameters for dye-sublimation printing: temperature, pressure and time.

Keywords: thermosublimation printing; thermal transfer printing; optical density; CMYK; metal plate; technological parameters; dye sublimation ink; sublimation paper. 